\title{
Community participation in bank of garbage: Explorative case study in Banyumas regency
}

\section{Partisipasi masyarakat pada bank sampah: Studi kasus eksploratif di Kabupaten Banyumas}

\author{
Agnes Fitria Widiyanto ${ }^{1} \&$ Rahab $^{2}$ \\ ${ }^{1}$ Faculty of Health Sciences, Universitas Jenderal Soedirman, Kampus Karangwangkal, \\ Purwokerto 53123 \\ ${ }^{2}$ Faculty of Economics and Business, Universitas Jenderal Soedirman Purwokerto, Jalan \\ HR. Boenyamin 708 Purwokerto 53122 \\ E-mail: afitriawidiyanto@yahoo.com¹ \& rahab_inc@yahoo.co.id ${ }^{2}$
}

\begin{abstract}
Waste bank is an activity that people do to reduce waste. The waste management activity through the establishment of a garbage bank becomes a very useful breakthrough, because people could save the waste which is exchangeable into money. The objective of this research is to know the inhibiting factors and the impetus for the community (targets) to participate in waste bank, covering behavior, knowledge, understanding, and community motivation. This research is an exploratory research with qualitative approach implemented in Banyumas district. Data collection is done through in-depth interviews using purposive sampling. Data were analyzed using interactive analysis. The results indicate that the presence of active waste banks in the community, as well as motivated by other community members. The development of the existing garbage bank in the society is unstable that there is a need to be support from various parties so that the garbage bank continues to progress and develop. Community knowledge of waste bank activities, including collection, transportation, community participation, prices or economic value of waste and recycling activities. Factors that encourage participation in waste banks, among others are motivation and environmental conscious behavior.
\end{abstract}

Keywords: society participation, trash bank, Banyumas

\begin{abstract}
Abstrak
Bank sampah merupakan suatu kegiatan yang dilakukan masyarakat untuk mengurangi sampah. Kegiatan pengelolaan sampah melalui mekanisme pendirian bank sampah menjadi terobosan yang sangat bermanfaat, karena masyarakat bisa menabung sampah yang kemudian dapat bisa digantikan menjadi uang. Penelitian ini bertujuan untuk mengetahui faktor penghambat dan pendorong bagi masyarakat (target sasaran) untuk berpartisipasi pada bank sampah, meliputi perilaku, pengetahuan, pemahaman, dan motivasi masyarakat. Penelitian ini merupakan penelitian eksplorasi dengan pendekatan kualitatifyang dilaksanakan di kabupaten Banyumas. Pengumpulan data dilakukan melalui wawancara mendalam dengan menggunakan purposive sampling. Data dianalisis menggunakan analisis interaktif. Hasil penelitian mengindikasi bahwa keberadaan bank sampah aktif di masyarakat, serta dimotivasi oleh anggota masyarakat lain. Perkembangan bank sampah yang ada pada masyarakat kondisinya tidak stabil, sehingga perlu dukungan dari berbagai pihak supaya bank sampah terus maju dan berkembang. Pengetahuan masyarakat tentang kegiatan bank sampah, meliputi kegiatan pengumpulan, pengangkutan, peran serta masyarakat, harga atau nilai ekonomi dari sampah serta kegiatan daur ulang. Faktor yang mendorong dalam berpartisipasi di bank sampah, antara lain motivasi dan perilaku sadar lingkungan.
\end{abstract}

Kata kunci: partisipasi masyarakat, bank sampah, Banyumas

\section{Introduction}

Banyumas is one of the regencies in Central Java, Indonesia, homing 1.707.474 population, which has been categorized as the district with a high level production of waste. Each year, the number of waste statistically increases which in 2015 reached 6.829 .896 per day. It causes many kilograms of waste was unable to be contained in the public landfill (Tempat Pembuangan Akhir or TPA). At the same year, it was accounted that only $10 \%$ of that waste which could be collected in the landfill while 
the rest had not been managed thoroughly. It led to the increase of high scale of pollution which at some point drove to such environmental hazard. Hence, a serious action was urgently needed to overcome the overwhelming production of waste in Banyumas.

The problem of waste in Indonesia has led the government to formulate a policy which approached this problem by involving all actors, both state, and society. One of the strategies initiated by the State Minister for the Environment to promote and to engage people's sensitivity toward the problem of waste particularly the household one is by implementing the Waste Bank (Bank Sampah). The Waste Bank refers to the mechanism in sorting out the waste both organic and non-organic by using the four integrated principles (1) reduce; (2) reuse; (3) recycle; (4) replace which involves social participation in its implementation. The waste bank principally is the social engineering to engage people's participation to overcome the problem of waste. It expects there is such innovation in managing the waste from the household level to the higher one by perceiving that the waste is as valuable as the money through which people could utilize it for economic purposes. Furthermore, the waste bank can also be the chance through which the economic opportunities emerge for the household. Thus philosophically, it turns back the waste from the problem to be economic resources for all people.

In Banyumas, the local government continuously manages the waste through the conventional ways such as collecting and transporting them to the landfill. However, it does not mean without problems. Due to the overcapacity of existing landfills (TPA Gunung Tugel, Tipar, and Kemutug), the local government plans to build the new one. Yet it has never been realized due to the lack of space they can afford. Since then, it is estimated that approximately only $65 \%$ of the total waste the local government could process at most. Hence the central government policy of Waste Bank may be the solution to overcome the problem of unmanaged waste in the district of Banyumas. This necessarily requires people active engagement and support to run.

Indonesian constitution mandates that everyone has an equal responsibility to the environment and waste management. According to the UU No. 182008 about the management of waste, it is stated in article 20 that people must be responsible for the waste management by using recyclable products. People as human actors which contribute to the production of the huge number of waste is driven to actively engage in the waste management process (Syarifudin, 2008). Active participation is the main principle in reducing the waste management problems. In Banyumas, through the PNPM Mandiri program, as a strategy to overcome the problem of waste management, the local government has endorsed people participation by reducing the production of waste in the level of the household. In doing so, the local government promotes the use of the waste bank established in four different villages as a pilot project. They are located in Arcawinangun and Kelurahan Mersi which is both in Purwokerto Timur Subdistrict, Rempoah of the Baturaden Subdistrict, and Tambaksari of the Subang subdistrict. Yet according to PNPM Mandiri program coordinator in Banyumas, the degree of participation is only $10 \%$ of the total households of the four projected villages which have been registered as the customers of the waste bank. The low level of people's participation, accordingly, is considered due to the ineffectiveness of the socialization and marketing strategy to the program beneficiaries so as it is less influencing in people's vision and behavior in managing their household waste.

According to the Banyumas District Environmental Agency (2011), data show that the volume of waste production in the district tends to increase reaching up to $21,4 \%$ each year. It is in line with the growing number of population and the household consumption pattern. Moreover, the peoples' habit of disposing of out their waste carelessly worsening the situation which causes waste to be more problematic. In the one hand, the lack of space in gathering waste through the conventional ways and the less number of participation in saving their waste to the waste bank leaves the huge number of waste still unmanaged. In the other one, social behavior on waste contributes to the increasing level of the waste problem which endangers inhabitant life as well as their natural environment due to the pollution of the waste. As Hadi (2005) points out that the uncomprehensive waste management is 
potential to arising social problems such as riot, community clash and stemming access to the landfill. Such efforts in managing the waste from the up and downstream points, from the waste producer to the waste collection are the way to overcome the waste problem which is at the same time promoting particular benefits by turning the waste as one of the economic resources. Hence, the waste bank program is basically not only beneficial in ecological aspect but also giving opportunities to the wider people in gaining its economic benefits by recycling the waste to be valuable commodities like organic fertilizer or other profitable secondary products.

Up to 2014 , it has been noted that there are 2.800 waste banks throughout Indonesia which increases to be 3.900 a year later (Tempo 2016). The success story of the waste bank in national level is inseparable with the strategies employed by the stakeholders in promoting people to engage in the waste bank. Social empowerment and education to the people are carried out by using social marketing approach which emphasizes the mixture of six (6) P including product; place; promotion; price; partnership; and policy. Indeed, the 6-P must be integrated with the government policy so that the implementation of the waste bank program can be socially and widely acceptable (Haldeman \& Turner 2009). The implementation of the waste bank program depends on how the formulation of social marketing strategies to render people's perception of the waste and its conventional ways in managing it from the household levels. Therefore it requires a precise strategic policy provoking social awareness and encouraging participation in overcoming the problem of waste through the waste ban program. The effective marketing and socialization design are expected to be able in engaging people in adopting the waste program voluntarily. The more people involve and adopt the waste bank program means the more the negative impact of the waste problem can be alleviated, particularly around the settlement areas. Furthermore, the waste bank program will contribute to increasing people's economic-living standard.

To reduce the problem of waste, it is necessary to change the conventional approach to the more proper one. Both policymakers and other related stakeholders must shift their approach from the end-pipe of the solution to the approach of the source. It means that the waste should not only be treated at gathering the waste from first collecting points until the landfill but also be managed from the source points which is the waste producer in the household levels (Syarifudin 2004). Principally, the approach of the source expects the reduction of waste volume which will have been collected to the landfill. The means to reduce the volume of the waste can be both sorting out the waste and the implementation of the 3-R tenets consisted of Reduce, Reuse, and Recycle (Syafruddin 2004). Therefore it is in line with what has been promoted by the State Minister for the Environment of Indonesia that the waste bank program is created to alter people's perception on the waste and promoting them as the active actor in managing the problem of waste sustainably through the intensive system. According to Kennedy (2010) to alter sustainably the social behavior through the social marketing requires several elements determining the implementation of the waste program which includes people's commitment, local policy, intensive communication and the related social norms.

Basically, the sustainable management of waste requires a holistic approach involving all stakeholders. The holistic approach is urgent in terms of its purpose in provoking social awareness and people interest from the various background in taking active participation in managing and reducing the problem of waste. The public authority, health service provider, academics, social activists and private sectors have boosted the discourse on the problem of waste and its potential threads together with the specific policy through which the effective sustainable strategy could be drawn up (Caniato, et al. 2014). However, it is also interesting to look at other perspectives. The other opinion states that behavior toward the waste which has been exercised in the everyday life has shaped people's collective behavior which settles relatively (Wibowo 2009).

People's participation in succeeding the waste program for reducing the pollution needs common understanding and commitment to its sustainability. However, not all people are aware of this issues. Of the many slogans in campaigning the waste reduction such as recycle and fertilizing the waste, it is 
only $37 \%$ of respondents who have done them in their lives (Ramang et al. 2007). Hence motivating each other in order to develop a better understanding of reducing the waste problem is still required.

In RT 50, the waste management is conducted by sorting out the non-organic one. They collect the sellable items to take benefit of its economic value. This action actually has reduced the environmental pressure (Aisyah 2013). In addition, to overcome such environmental problem, recycling the waste can be an alternative to developing family entrepreneurship (Lubis 2002). Furthermore, several factors have been noted which are influencing the waste management such as level of age, education, income, jobs and family member (Yuliani et al. 2012). However, among the above potential discourses on the waste management, it is also worth to investigate the push as well as obstacle factors. Both push and obstacle factors are important in discussing the waste management program particularly in understanding the extent to which the program is viable among the beneficiaries. Thus this research aims to explore both factors among the people in Banyumas based on their behavior, knowledge, understanding and social motivation regarding on their participation in the waste bank program so far.

\section{Research Method}

This research employs a qualitative method which is carried out among the waste banks in Banyumas. The qualitative method is useful to understand comprehensively problems which are undergone by the waste existing banks. Research subjects are determined by their membership and participation in the waste bank. They have been chosen as purposive sampling from them researchers gain useful material of this research. Since it aims to elaborate reasons and challenges of people participation in the waste bank program, this research treats human as the primary instrument by which data are collected by doing observationand interview. Theinterview guidelines, checklistand voicerecorderare used inthisresearch.

Data are analyzed by using interactive analyses while triangulation technique is used to measure its objectivity. Steps and component of this research consist of data collection, reduction, presentation of data and drawing the conclusion (Miles \& Huberman 2007). The quality test of the data is carried out by using source triangulation technique which includes checking and comparing the validity of such information based on the different time and tools of data collection. As Moleong (2001) points out, the triangulation technique is used to attest the degree of data trust on the finding among several data source by using the similar method.

\section{Result and Discussion}

\section{Behaviour}

The existence of the waste bank in this research filed generally occurs due to the people's endorsement of the Banyumas District. The increasing volume of the waste and lack of infrastructure have encouraged people to create a self-help sustainable waste management model by maximizing all resources and potential they have. Through a consensus, they generally agree to create the waste bank. The Focus Group Discussion (FGD) carried out with the management, Non-Governmental Organizations (NGOs), Health Agency, Environmental Agency, and the waste bank customer shows that the waste bank and its implementation in Banyumas District is one of the waste management model recommended by the State Minister of Environment. Indeed, the Environmental Agency and DCKTR will support the program as long as people also carry out in practice the waste bank program such as establishing the waste bank operational board, registering themselves as the waste bank customer, and together agreeing to the location of the waste bank operational site. Furthermore, the Environmental agency will support by providing the waste bank office and the related tools and devices such as bins and rubbish wagon. As it is noted in an interview:

"The need (for the waste bank) is due to the volume of waste. There are 500 houses 
here and they produce approximately seven wagons of waste per day. At the same time, the landfill is too small to contain that volume while the garbage collection is only once in a week so that the landfill is over of its normal capacity" (Wisnu, Satria Mandiri).

"In this area, the waste is collected three times in a week. However, housewives usually sort the recyclable ones then sell them to the agent" (Bu Tejo, Arcawinangun).

The implementation of the waste bank in Banyumas District will be successful only if there are the group of people which is active in doing so. The group will provoke people to participate in the waste bank program. These active actors will promote people to register themselves as the waste bank customer. Furthermore, the waste bank customer will have enforced their task in managing their own waste in the level of the household. Both collecting and sorting out the waste are their primary task as the customer. The waste will have been sorted out according to their quality and recyclability that is organic and non-organic. Organic waste is usually recycled to be the fertilizer while the non-organic one is to be sold in the waste bank. Thus, being the waste bank customer is not only preserving our environment directly but also creating economic opportunity for the household.

The establishment of the waste bank in particular place will have reduced volume of waste collection. The waste bank can be the dropping point for the expired product which means reducing the circulation of the unsed but recyclable products. Moreover, the waste bank also helps the government in reducing the high number of waste which this program expects to decrease the volume of garbage in the limited landfills. The enforcement of 3-R in the household level through the waste bank operating program is also targeted to overcome the problem of waste thoroughly and integrated so that the final achievement of the waste management policy in Indonesia can be implemented comprehensively (Kemen 2012).

\section{Knowledge}

According to the data, people's knowledge about the waste bank program varies. It describes lack of understanding of the essence and operation of the waste bank itself. Some people think that the waste bank program manages the collected waste by using composter method while some others consider it is like the manual method where the waste is collected in the household level and then the waste collector will pick them later. This lack of understanding and proper knowledge about the waste bank and its operational method affect the low level of participation to become the waste bank customer. In addition to participation, the waste bank program actually requires the appropriate method which is compatible with local habits and cultures.

The waste bank is one of the solutions in handling the arising volume of waste which is still unmanaged thoroughly. It presupposes the sorting out the waste which separates the recyclable as well as saleable waste. The operating system of the waste bank is seemingly similar to the bank in general. Aside from accounting and banking management procedures, the waste bank must also have the customers. If in the financial banking the customers deposit their money, in the waste bank they save their recyclable and saleable waste. The waste bank management then gives economic rewards to their customers who deposit their waste to the bank based on a number of the deposited waste. Indeed, the waste bank management must have the entrepreneurial skill and be innovative in managing. The more innovative the management means the more economic profit and benefit gained from managing the waste. Furthermore, the waste bank concept, both directly and indirectly, promotes the green campaign in order to save our environment in addition to giving a lesson of saving for the people particularly the younger generation. Hence, the waste bank method also functions to empower society in order to respect to the environment and natural resources.

The transcript below describes people understanding on the waste bank concept: 


\begin{abstract}
"Based on the socialization in the PKK meeting, it was only the explanation on the composter and the related devices to used it such as the bin" ( $\mathrm{Bu}$ Tejo, Arcawinangun).

"The conventional way of waste management was that the household waste was usually picked up every day but in the waste bank they collect it first the was picked up later. Yet it was no longer operated. Recently, the waste is collected in one or two boxes and then it is weighed to calculate its price. Once the weight measures the waste is bought according to the standard price and the money is to become RT budget" (Bu Wirda, Bantar Soka).

"The most difficult problem in the waste bank is the operational cost which is unavailable so that the program is unlikely to run". (Wisnu, Satria Mandiri).

"The most challenging aspect of running the waste bank concept is that there is no standard price of waste in the level of waste collector. The individual-based waste collection is carried out indirectly while in the huge container waste collection still uses the permanent container system which is the unportable container" (Ikhsandri 2014).
\end{abstract}

People's knowledge of the waste bank program generally consists of the activities including collecting, picking up, participation, economic value, and recyclability of the waste. The evidence shows that people's understanding on the recycling the waste and its economic value is useful so that they can separate and sort out their own waste such as plastic which is recyclable (Ozkan et al. 2014). Moreover, plastic can also be transformed to be alternative liquid fuel (Kadir 2012).

The success of the waste bank program can be measured which one of them by checking the existence of the illegal landfill. It lies in an assumption that principally the waste bank program is purposed to reduce the illegal landfill or the cumulation of waste in many places. The existence of illegal landfills indirectly describes their people's commitment and behavior on reducing the problem of waste (Mulasari \& Sulistyawati 2014). The waste bank program is beneficial for family empowerment, particularly, in increasing women knowledge on the need to reducing and eliminating the impact of waste (Rustina et al. 2014).

\title{
Understanding
}

People's understanding of the waste bank varies relating to whether the waste bank program is important for their lives. Some think that the program can be the solution while the majority is still careless. Most of them consider that if they involve in the waste bank program it makes them in touch with the waste frequently. They are afraid that they will be contaminated by diseases if they are too frequent in working with the waste. In addition to this reason, their own business and schedule have influenced their concern and attitude toward the waste. As it is stated by an informant:

"I think it is not really interesting for me due to the reason of healthy. So I prefer to concern on my duty as a housewife". (Bu Tejo, Arcawinangun).

For a long time, the management of waste rests on the conventional method where they rely on the final landfill. However, since the introduction of the waste bank program, people's habits change gradually. They who used to amass their waste, recently they have sorted it out and chosen the valuable items. 
“....changing people habits to sort out and deposit their waste. If it could run regularly, the result would be sufficient to budget the operational cost”. (Wisnu, Satria Mandiri).

UU no. 182008 on the Waste Management and PP No. 812012 mandate the need of changing paradigm in managing the waste from the paradigm of collect-pick up-throw out to become reduction and direct action in managing the waste. Reducing number of waste propose to increase the awareness of both people, the government, and private sectors toward the waste they produce. Reducing does not only mean decreasing the number of waste, moreover, it is also followed by the act of reuse items which is considered as feasibly usable and of recycling the recyclable goods. Hence it is suitable for what the government has campaigned which is well known as the 3-R, Reduce-Reuse-Recycle (The State Minister of Environment 2008).

The statistic shows that the establishment of the waste bank in Indonesia up to February 2012 reached 471 banks which had been operating with approximately 47.125 customers. They had deposited their waste which roughly reached $755.600 \mathrm{~kg} / \mathrm{month}$ on average with the velocity of capital up to $\mathrm{Rp}$. 1.648.320.000 per month. This number of waste bank doubled in several months which was accounted in May 2012 the waste bank number in Indonesia attained 886 active waste banks. Their customers also increased doubly to become 84.623 with the average number of waste roughly $2.001 .788 \mathrm{~kg} /$ month resulting Rp.3.182.281.000 per month (Kemen 2012).

\section{Motivation}

The waste bank program more or less is motivated by people's encouragement who asks for an innovation in reducing the problem of waste. As it is stated by an information:

"If the program is operated in this area, I will help motivating housewives to engage in the program". (Bu Tejo, Arcawinangun).

The waste bank customers also expect the program can be implemented sustainably. It is due to the program is vital in reducing the waste problem. Sorting out and collecting the waste in the waste bank is significant in reducing the unmanaged waste which usually occurs in the neighborhood.

"I participate in collecting and sorting the waste out. I separate the recyclable waste.

I expect the sustainability of this program". (Bu Wirda, Bantar Soka).

The mechanism in the waste bank is generally similar with the conventional banks. The only difference is that if in the conventional bank people deposit their money and will be getting back money but in the waste, bank customers deposit their recyclable waste however they can draw it back in the form of money. This is what has been experienced by the waste bank Gemah Ripah in the Badegan village, Bantul, Yogyakarta which is pioneered by a lecturer namely Bambang Suwerda of the Polytechnic of Health of the Ministry of Health of Yogyakarta in 2008 (Prihtiyani 2008). Indeed, people expect the waste program can run effectively.

The evidence shows that the existence of the waste bank reduces approximately $10 \%$ of the total number of waste in the landfill. Thus the waste bank program affects in preserving the landfill itself since the landfill will be operated according to its actual capacity (Priambodo 2012). Another opinion says that the routine carriage of waste with several devices including the bin, trash wagon, hoe, and truck will give benefit for the sustainable management of waste (Sudiran 2005, Wahyono 2001). 


\section{Value}

The development of the waste bank program is unstable. Lack of understanding and knowledge about the program leads to the low level of participation in particular society. It necessarily urges stakeholders to support the program so that it can progressively grow. In Banyuwamas District, especially in Arcawinangun, the waste bank program run effectively in the beginning. However, since the changing board and management affected the program delivery of the waste bank. As it was shown in an interview:

"In the past, the program run well. But since the internal problem, it went vacuum.
The new management could only operate the waste bank in three months but after
all, they stopped. The waste bank so fluctuated" (Bu Tejo, Arcawwinangun).

People's participation in planning the program will emerge the sense of belonging to the program. Hence the field officer of the waste bank should ask to plan the program altogether, from the planning session up to the evaluation stage (Setyawan 2010).

The number of small-scale enterprises at the national level is high particularly in developing countries. Often the small scale business is limited to the availability of economic capital and their economic vision. Number and type of waste are carried out by the employing recycling method (Top 2014). The management of waste by composting, incineration (burning), and recycling paper and plastic garbage is effectively practiced in The City of Bukittinggi (Yeni et al. 2012).

According to the analysis result, both using the dynamic system and priority scaling AHP and Benefit-Cost ration $(\mathrm{B} / \mathrm{C})$, so that the management of waste in the province of DKI Jakarta should be carried out step by step. First is composting. It considers the existing problem such as pollution, people refusal, and so on, and the related aspects, particularly the social aspect which has $53,8 \%$, the highest preference compared to other aspects. It also considers the investment feasibility based on B/C ratio 1,41, and the drop piles of waste. Secondly, it can be managed by employing incinerator. Handling the problem of waste by using incinerator is conducted after the socialization process to the adjacent societies. It ensures the understanding so that conflict between societies and waste managing officers can be eliminated. This method is also effective to keep the investment feasibility based on the Benefit-Cost ratio (B/C) higher one point $(1,04)$ and its effectivity in reducing the waste piles up to $66 \%$ (Surjandari et al. 2009).

\section{Conclusion}

Recently, the development of the waste bank in our society is still unstable and call of public attention. Support from various elements is still needed to developing this program. Factors which encourage this program are motivation and environmental awareness among societies. In addition, several obstacles factors also exist including the internal problem during the changing board and management.

\section{References}

Aisyah (2013) Pengelolaan sampah rumah tangga berbasis masyarakat di RT 50 Kelurahan Sungai Pinang dalam Kecamatan Samarinda Utara. Jurnal Beraja Inti 2 (12). http://e-journal. fhunmul.ac.id. 
Anggraini F (2011) Aspek kelembagaan pada pengelolaan tempat pemrosesan akhir sampah regional (Institutional aspects in the management of regional final waste processing site). Jurnal Permukiman, 6 (2):65-74.

Apriadi P (2012) Bank Sampah dan Program Lingkungan Yayasan Unilever. [Diakses 23 Juli 2013]. $\mathrm{http} / \mathrm{www}$. unilevergreenandclean.co.id/greenandclean.

Caniato M, Tudor TL, \& Vaccari M (2014) Understanding the perceptions, roles and interactions of stakeholder networks managing health-care waste: A case study of the Gaza Strip. Waste Management 35:255-264. http://dx.doi.org/10.1016/j.wasman.2014.09.018.

Hadi SP (2005) Demensi Lingkungan Perencanaan Pembangunan. Yogyakarta: Gadjah Mada University Press.

Haldeman T \& Turner JW (2009) Implementing a community-based social marketing program to increase recycling. Social Marketing Quarterly XV (3).

Ikhsandri (2014) Kajian infrastruktur pengolahan sampah di kawasan berkembang Jakabaring Kelurahan 15 Ulu Kota Palembang. Jurnal Teknik Sipil dan Lingkungan, 2 (1).

Jumar, Fitriyah N, \& Kalalinggi R (2014) Strategi pengelolaan sampah rumah tangga di Kelurahan Lok Bahu, Kecamatan Sungai Kunjang, Kota Samarinda. e-Journal Administrative Reform, 2 (1):771-782.

Kadir (2012) Kajian pemanfaatan sampah plastik sebagai sumber bahan bakar cair. Dinamika, Jurnal Ilmiah Teknik Mesin, 3 (2).

Kemen LH (2012) Profil Bank Sampah 2012. Jakarta: Kementrian Lingkungan Hidup.

Kementrian Negara Lingkungan Hidup (2008) Status Lingkungan Hidup Indonesia 2007. Jakarta.

Kennedy AL (2010) Using community-based social marketing techniques to enhance environmental regulation. Sustainability, 2 (1):1138-1160.

Lubis A (2002) Pemanfaatan limbah kertas untuk cenderamata dan pemasarannya. Jurnal Pengabdian Kepada Masyarakat, 8 (29).

Miles MB \& Huberman AM (2007) Analisis Data Kualitatif. Jakarta: Universitas Indonesia Press.

Moleong LJ (2001) Metodologi Penelitian Kualitatif. Bandung: PT. Remaja Rosda Karya Bandung.

Özkan K, Ergin S, Isik S, \& Isikli I (2014) A new classification scheme of plastic wastes based upon recycling labels. Waste Management 35 (2015):29-35. www.elsevier.com/locate/wasman.

Priambodo G (2012) Mengangkat Derajat Sampah lewat Bank Sampah. http://green.kompasiana. com/polusi/2013/07/15/mengangkat-derajat-sampah-lewat-bank-sampah-577051.html.

Prihtiyani E (2008) Masyarakat Bandegan Dirikan Bank Sampah. [Accessed 7 August 2013]. http:// www.kompas.com/read/xml/2008/08/07/18300420/masyarakat.badegan.dirikan.bank. sampah.

Ramang R, Enri D, Padmi T, \& Rahardyan B (2007) Pola penangan sampah di daerah perkotaan berdasarkan karakteristik tipe rumah (Studi kasus Kota Cimahi). Jurnal Teknik Lingkungan, $13(1): 8-16$.

Rustina, Nursasi, Budiati, Syahreni, \& Fitriyani (2014) Pengaruh pemberdayaan keluarga terhadap status kesehatan bayi berat lahir rendah di Kota Jakarta. Makara J. Health Res., 18 (1):19-24.

Setiawan Y (2010) Karakteristik Char Sampah Organik dan Anorganik Hasil Pirolisis, Prosiding Seminar Nasional Teknik Mesin UMY, Yogyakarta.

Sudarwanto S (2010) Peran strategis perempuan dalam pengelolaan limbah padat bernilai ekonomi. Jurnal Ekosains II (1).

Sudiran (2005) Instrumen sosial masyarakat Karangmumus Kota Samarinda dalam penanganan sampah domestik. Makara, Sosial Humaniora, 9 (1):16-26.

Suprapto (2005) Dampak masalah sampah terhadap kesehatan masyarakat. Jurnal Mutiara Kesehatan, $1(2)$.

Mulasari SA \& Sulistyawati (2014) Keberadaan TPS legal dan TPS ilegal di Kecamatan Godean Kabupaten Sleman. KEMAS, 9 (2):122-130. http://journal.unnes.ac.id/nju/index.php/kemas.

Surjandari I, Hidayatno A, \& Supriatna A (2009) Model dinamis pengelolaan sampah untuk mengurangi beban penumpukan. Jurnal Teknik Industri, 11 (2):134-147.

Syafruddin (2004) Pengelolaan Sampah Berbasis Masyarakat. Prosiding Diskusi Interaktif Pengelolaan Sampah Terpadu, Program Magister Ilmu Lingkungan Universitas Diponegoro, 
Semarang.

Wahyono S (2001) Pengelolaan sampah kertas di Indonesia. Jurnal Teknologi Lingkungan, 2 (3):276280.

Wibowo I (2009) Pola perilaku kebersihan: Studi psikologi lingkungan tentang penanggulangan sampah perkotaan. Makara, Sosial Humaniora, 13 (1):37-47.

Tempo(2016)BankSampahPerbaikiEkonomi Masyarakat.https://m.tempo.co/read/news/2016/03/.../ bank-sampah-perbaiki-ekonomi-masyarakat.

Top Y (2014) Waste generation and utilisation in micro-sized furniture-manufacturing enterprises in Turkey. Waste Management 35:3-11. http://dx.doi.org/10.1016/j.wasman.2014.09.028.

Yenni R, Indah S, \& Laylani W (2012) Study of solid waste generation, composition and characteristic of domestic solid waste in Bukittinggi City. Jurnal Teknik Lingkungan, UNAND, 9 (1):1-12.

Yuliani, Rohidin, \& Bieng (2012) Pengelolaan sampah di Kecamatan Kota Manna Kabupaten Bengkulu Selatan melalui pendekatan sosial kemasyarakatan. Naturalis, 1 (2). 